\title{
Significance of Potassium in Genesis of Arrhythmias in Induced Cardiac Ischaemia
}

\author{
PETER TAGGART, J. D. H. SLATER
}

British Medical fournal, 1971, 4, 195-198

\begin{abstract}
Summary
Paired biopsy specimens from the right or left atrial appendage have been taken from patients undergoing cardiopulmonary bypass surgery after various periods of intermittent coronary artery occlusion and analysed for potassium, sodium, and chloride content, total tissue water, and extracellular fluid volume.

Tissue potassium content is reduced after coronary artery occlusion, and potassium loss bears an apparently linear relationship to the duration of occlusion. After 150 minutes of occlusion the potassium content had decreased by nearly $50 \%$.

For the first 50 minutes of occlusion the myocardial cells swelled at the expense of the extracellular fluid volume. Thereafter there was movement of water in the opposite direction, with subsequent cell shrinkage.

The loss of potassium and the alteration in cellular hydration exert profound effects on the calculated gradient of potassium across the cell membrane. This is discussed in relation to the arrhythmias and low cardiac output after myocardial ischaemia. An attempt to rationalize treatment is made.
\end{abstract}

\section{Introduction}

Depolarization and repolarization in cardiac muscle depend on a potassium-dependent and sodium-dependent potential difference across the muscle cell membrane (Langer, 1968). After bypass surgery or myocardial infarction an irregular or inadequate contractile response is a frequent cause of death. The role of potassium is complex. Experimental coronary artery occlusion is well known to result in an increased potassium efflux in the veins draining the occluded area (Dennis and Moore, 1938; Harris, 1966). This net loss of potassium from the myocardium has been causally related to the development of arrhythmias in the period following occlusion (Harris et al., 1954; Regan et al., 1967), though the anatomical site of the occlusion is also important (Thomas et al., 1970). Depletion of myocardial potassium content has been shown in dogs after coronary artery ligation (Jennings et al., 1964; Zugibe et al., 1966) in humans after myocardial infarction (Iseri, et al., 1952; McVie, 1970), and in both human atrium (Taggart and Slater, 1970) and papillary muscle (Singh et al., 1969) after anoxic arrest during cardiopulmonary bypass surgery.

Arrhythmias may be associated with profound and rapid changes in the serum potassium concentration, and in these circumstances they often respond to correction of the serum concentration (Levine et al., 1951; Bettinger et al, 1956; Surawicz, 1966). However, most arrhythmias occur when

Middlesex Hospital Medical School, London W1P 7DE

PETER TAGGART, M.R.C.P.(LOND., ED.), British Heart Foundation Research Fellow

J. D. H. SLATER, F.R.C.P., Senior Lecturer; Consultant Physician, Middlesex Hospital the serum potassium concentration is comparatively normal (Surawicz, 1966). Though intravenous potassium is often effective, there is a poor correlation between the serum potassium concentration on the one hand and both the incidence of arrhythmias and their response to intravenous potassium on the other. While many other factors are highly relevant (Raab, 1969), such as myocardial catecholamine action (Cox and Robertson, 1936; Shanks and Dunlop, 1967; Schaal et al., 1969; Ceremuzynski et al., 1969; Ebert et al., 1970; Vanderbeek and Ebert, 1970), temperature (Klein et al., 1968), glucose metabolism (Prasad and Callaghan, 1969), and variations in electrophysiological characteristics of different cardiac cell types (Hoffman and Cranefield, 1960), some of the complexities may be explained if the potassium gradient across the myocardial cell membrane is considered.

In a previous unpaired study we have shown a considerable depletion of potassium in human atrial biopsy specimens removed during bypass surgery (Taggart and Slater, 1970). We have now investigated the validity of the earlier observations by performing a paired study (at least two biopsies from most patients) and by relating the changes observed to the length of time for which the coronary circulation had been occluded. In addition, we have assessed changes of the potassium gradient by determining the water distribution between intracellular and extracellular compartments after various periods of coronary artery occlusion.

\section{Patients}

Twenty-five biopsy specimens were taken from the right or left atrial appendage from 12 patients (eight men aged 39-67 and four women aged 43-54) at selected times during open heart surgery. Cross clamping of the aorta with intermittent coronary artery perfusion allowed the specimens to be taken after timed periods of occlusion or reflow. In all 12 patients the aortic valve was replaced. In one patient mild mitral valve disease was also present. Bypass was maintained with a pump oxygenator (New Electronic Products Ltd.) with cooling to $28^{\circ} \mathrm{C}$ (oesophageal temperature). Preoperatively no patient had evidence of heart failure and the serum concentration of sodium, potassium, chloride, bicarbonate, and urea were normal. Ten had received small doses of digitalis and four had been receiving diuretics in addition.

The total occlusion time is defined as the sum of the individual periods for which the appropriate coronary artery had been occluded before sampling; it takes no account of the amount or frequency of intermittent reflow. Unless otherwise specified, a period of 3 to 15 minutes of reflow was allowed after the final period of occlusion before the biopsy specimen was removed.

\section{Analytical Procedures}

The samples were quickly blotted to remove surface moisture, trimmed of visible fat and connective tissue, and divided into two roughly equal portions. The first of these was further subdivided into 2 to 12 portions, which weighed between 10 and 30 ing, and analysed for sodium, potassium, and chloride content and total tissue water. The second 
was incubated with ${ }^{14} \mathrm{C}$-inulin, similarly subdivided and analysed for inulin, sodium, potassium, and chloride content and total tissue water.

\section{ELECTROLYTES AND TOTAL TISSUE WATER}

Each subdivided portion was placed on an aluminium pan (Flear and Florence, 1961) (1.0-1.6 mg) and weighed on a microanalytical balance (Mettler Ltd.). We confirmed the fact that there was an exponential loss of water at room temperature (Paradise, 1963). Therefore, each portion was weighed three times at precisely timed intervals, and the weight at zero time was determined by extrapolation on semilogarithmic paper. The tissues were then dried overnight at $105^{\circ} \mathrm{C}$ to constant weight and cooled in a desiccator. The weight of total tissue water was taken as the difference between the wet and dry weights. There was a small gain of water after removal from the desiccator but it was too small to warrant correction.

Fat was extracted by soaking overnight in petroleum ether (B.P. $40-60^{\circ}$ ). The tissues were again dried to constant weight and the difference between the two dry weights was taken as the weight of neutral fat. The fat-free dry tissue was then soaked for 14 to 16 hours in $0.1 \mathrm{~N} \mathrm{HNO}_{3}$ at room temperature. Sodium and potassium were estimated flame photometrically and chloride potentiometrically (AmincoCotlove micropotentiometer, American Instrument Company Inc.) (Cotlove et al., 1958). Our own observations and those of others (Flear and Florence, 1961) have shown that the times used for drying, defatting, and extraction of sodium, potassium, and chloride are more than sufficient for tissue portions of this size.

\section{INULIN DIFFUSION VOLUME}

Full validation of our method for the in-vitro determination of the inulin space will be described elsewhere. The tissue was incubated for three hours at $37^{\circ} \mathrm{C}$ in plasma taken from the patient at the same time as the biopsy specimen, with a tracer quantity of hydroxymethyl- ${ }^{14} \mathrm{C}$-inulin (Radiochemical Centre, Amersham). The medium was gassed vigorously and continuously with a mixture of warmed and moistened $97 \% \quad \mathrm{O}_{2}$ and $3 \% \quad \mathrm{CO}_{2}$. A second gas mixture of warmed $93 \% \mathrm{O}_{2}$ and $7 \% \mathrm{CO}_{2}$ was injected to maintain a constant $\mathrm{pH}$ of 7.4 , controlled by an automatic $\mathrm{pH}$ titrator (Radiometer TTTII). The tissue was then subdivided and processed as described for the determination of sodium, potassium, and chloride. In addition to the estimation of these three ions as described above, a small quantity $(0.5 \mathrm{ml})$ of the elution fluid was counted in a Packard liquid scintillation spectrometer. This method yields a recovery of $98 \%$ $\pm 1 \cdot 1$ (S.E. of mean) carbon-14 for the entire extraction process.

During the incubation procedure variable amounts of chloride are gained by the tissues. Previous experiments have shown a linear relationship between the gain of chloride and that of inulin, so that the inulin/chloride ratio remains constant. Owing to the alterations that occur in the composition of tissue during incubation, which may be inevitable despite the best possible conditions (Vick et al., 1970), it is unsound to apply an inulin space, determined by an in-vitro incubation on one portion of tissue, to an adjacent portion that has not been incubated. From our studies on skeletal muscle on the relationship between inulin and chloride on incubated normal and damaged tissue we have developed a method of extrapolating to a theoretical inulin space of an adjacent non-incubated portion on the basis of its chloride content.

Data analysis was carried out by using the statistical package which is available in the I.B.M. system 360. Regression lines were computed with the least squares fitting technique, analysis being carried out to the fourth order fit.

\section{Results}

The relationship between tissue potassium $\left(\mathrm{K}_{\mathrm{T}}\right)$ expressed as $\mathrm{mEq} / 100 \mathrm{~g}$ fat-free wet weight (F.F.W.W.) and the total period of occlusion of the appropriate coronary artery is presented in Fig. 1. The individual points are the result of analysis of 121 portions of 25 biopsy specimens from 12 patients with aortic valve disease. The 25 specimens comprised two from each of six patients, three from two patients, four from one patient, and a single specimen from the remaining three patients.

The results indicate a loss of tissue $K$ (on a fat-free wet weight basis) which is linearly related to the total period of occlusion of the coronary artery likely to be supplying the area from which the biopsy specimen was taken. The computed regression line shows a loss of $2.95 \mathrm{mEq} / 100 \mathrm{~g} \mathrm{F.F.W.W.}$ $(50.1 \%$ of the initial value) after a total period of 157 minutes' occlusion. The rate of loss is $0.078 \mathrm{mEq} / 100 \mathrm{~g} \mathrm{F.F.W.W./min,}$ or $1 \mathrm{mEq} / 100 \mathrm{~g}$ F.F.W.W./53.2 minutes.

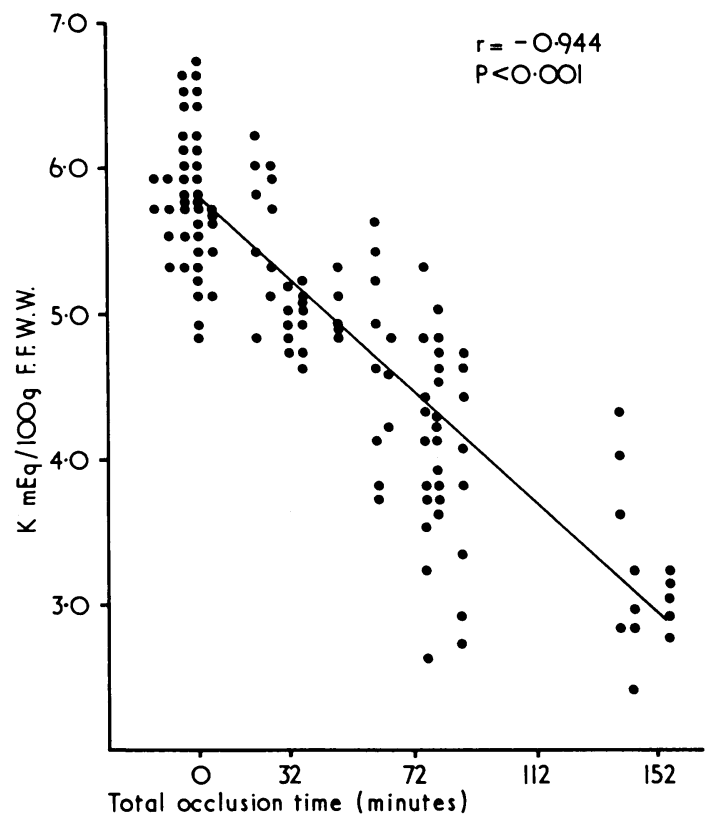

FIG. 1-Relationship between potassium content of atrial samples and total period of occlusion of the appropriate coronary artery.

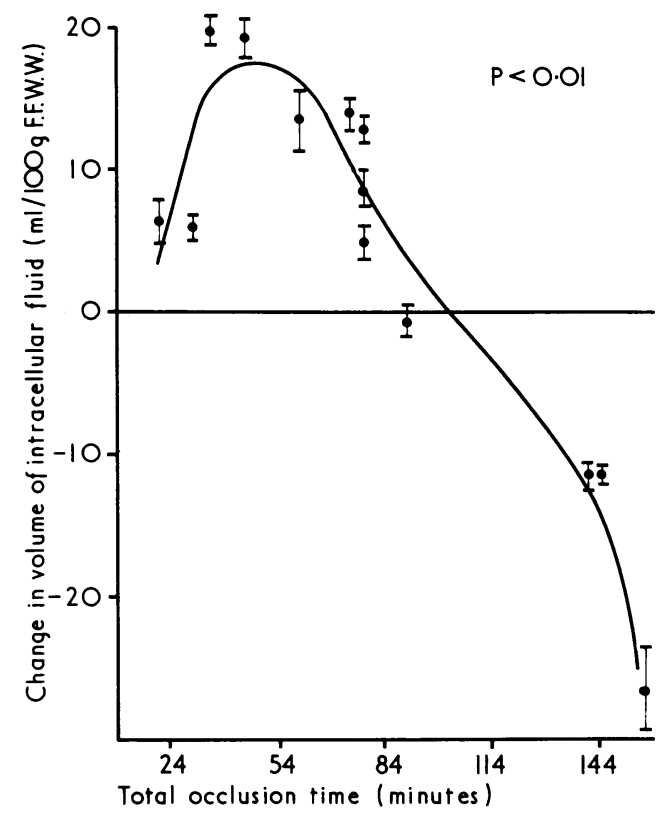

FIG. 2-Change in intracellular fluid volume after various periods of total coronary artery occlusion. 
Biopsy specimens removed after relatively short periods of coronary artery occlusion show an increase in the volume of intracellular fluid, whereas those removed after longer periods show a decrease in volume (Fig. 2).

The mean value for the intracellular fluid volumes of the subdivided portions of the initial biopsy specimen was obtained for each patient. These values were then subtracted from each individual subdivided portion of the later specimen taken from the same patient and plotted as its mean difference and S.E. of mean. The total water content of the tissue varied only slightly; there was a random increase of $1-2 \%$ after coronary artery occlusion. Consequently, variations in the state of intracellular hydration occur almost entirely as a result of redistribution of water between the extracellular and intracellular compartments.

\section{Discussion}

Our previous observations showed a mean $\mathrm{K}$ content of atrial biopsy specimens removed after bypass in nine patients of $3.18 \pm 0.05$ S.E. of mean $(\mathrm{mEq} / 100 \mathrm{~g} \mathrm{~F}$.F.W.W.) as compared with a mean value of $6.08 \pm 0.06$ in samples taken before bypass from a second group of nine patients (Taggart and Slater, 1970). Similar findings were obtained by Mandal et al. (1969) in atrial biopsies. The present study, while confirming our previous findings, shows a linear relationship between the tissue $\mathrm{K}$ and total period of coronary artery occlusion (Fig. 1). This relationship is present despite a number of variable factors such as the possible dominance of one or other coronary artery, the adequacy of perfusion by coronary artery cannulae, the relative length of the occlusive and reflow periods, the lack of homogenicity of atrial tissue, and the possible influence of trauma in the process of securing biopsy specimens.

The degree of intracellular hydration is fundamentally important in the determination of the potassium concentration gradient across the cell membrane $\frac{\left[\mathrm{K}_{1}\right]}{\left[\mathrm{K}_{\mathrm{o}}\right]}$, where $\left[\mathrm{K}_{1}\right]$ is the intracellular potassium concentration and $\left[\mathrm{K}_{\mathrm{o}}\right]$ is the extracellular potassium concentration. For the purpose of the ensuing discussion $K_{0}$ is considered as synonymous with the serum potassium concentration. As has been shown in Fig. 2 our data indicate an initial movement of extracellular fluid into the cell, producing cellular swelling reaching a maximum value after a total of about 50 minutes of ischaemia. It is of singular interest that periods of occlusion of longer duration result in a movement of water in the opposite direction, the original intracellular and extracellular volumes being restored after about 100 minutes, following which progressive cell shrinkage occurs throughout the remainder of the period we have studied. It is possible that inulin may diffuse into cells during ischaemia and so distort this interpretation. Since inulin and chloride behave similarly and since their diffusion coefficients are so different we consider that to be most unlikely. Even if there were a small

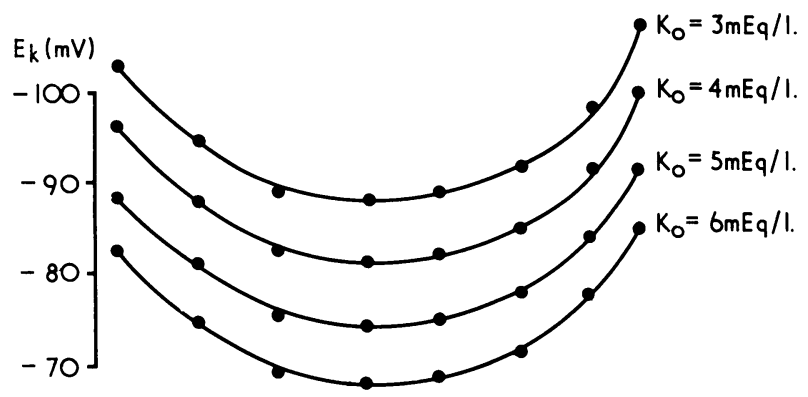

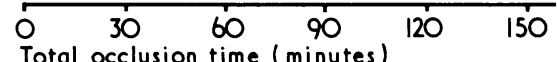

FIG. 3-Values for resting membrane potentials (Ek) calculated from our data for different values of extracellular potassium $\left(\mathbf{K}_{0}\right)$ after various periods of coronary artery potassium amount of cell penetration in ischaemic tissue the pattern of the calculated potassium gradients (Fig. 3) would not be altered.

Tissue potassium is almost entirely intracellular, so that if this movement of water were not taken into account it might be inferred that as tissue $\mathrm{K}$ is lost so a corresponding fall in the gradient $\frac{\left[\mathrm{K}_{\mathrm{o}}\right]}{\left[\mathrm{K}_{1}\right]}$ would occur. However, as this gradient is a concentration gradient, the initial increase in the intracellular water, by further diluting the already depleted intracellular $\mathrm{K}$, exaggerates the fall. The subsequent decrease in intracellular water not only minimizes it but actually increases the gradient despite a further fall in $K_{1}$. This initial fall and subsequent increase of $\frac{\left[\mathrm{K}_{1}\right]}{\left[\mathrm{K}_{\mathrm{o}}\right]}$ is reflected in the resting membrane potention $\left(E_{k}\right)$ calculated for potassium by using the Nernst Equation, $\mathrm{E}_{\mathrm{k}}=\frac{\mathrm{RT}}{\mathrm{F}}$ In $\frac{\left[\mathrm{K}_{1}\right]}{\left[\mathrm{K}_{\mathrm{o}}\right]}$ (where $\mathrm{R}$ and $\mathrm{F}$ are the gas and Faraday constants and $T$ the absolute temperature). Though the Nernst equation is only an approximation, we have calculated $E_{k}$ for the values of $\left[\mathrm{K}_{1}\right]$ obtained from our data after various periods of coronary artery occlusion (Fig. 3 ). The $\left[K_{1}\right]$ values have been obtained from (1) the mean values of $\mathrm{K}_{\mathrm{T}}$, and extracellular and intracellular fluid volumes in biopsy specimens removed before coronary artery occlusion, (2) the regression line relating $\mathrm{K}_{T}$ to total occlusion time (Fig. 1), and (3) the regression line relating the shift of extracellular and intracellular fluid to total occlusion time (Fig. 2). $E_{k}$ has been calculated for theoretical values of $\mathrm{K}_{\mathrm{o}}$ of $6,5,4$, and $3 \mathrm{mEq} / 1$. It can be seen that for each value of $K_{o}$ represented $E_{k}$ becomes initially less negative as a consequence of coronary occlusion. After a total period of about 50 minutes, as water begins to move in the opposite direction, $\mathrm{E}^{k}$ slowly increases until after 120 minutes a rapid increase occurs.

Let us consider now the values of $\mathrm{E}_{\mathrm{k}}$ calculated for different values of $\mathrm{K}_{\mathrm{o}}$. Raising or lowering the serum $\mathrm{K}$ much above or below $5 \mathrm{mEq} / 1$. before any coronary artery occlusion has occurred would be expected to result in depolarization or hyperpolarization respectively. Equally, correcting the serum $\mathrm{K}$ towards a figure of $5 \mathrm{mEq} / \mathrm{l}$. before any coronary artery occlusion should move $E_{k}$ back towards its normal resting value of -90 $\mathrm{mV}$. However, after 60 minutes' ischaemia the lower values of plasma $\mathrm{K}$ give $\mathrm{E}_{\mathrm{k}}$ values closer to $-90 \mathrm{mV}$ than the "normal" values of serum $K$. Intravenous $K$ given to correct the serum $K$ from, for example, 3 to $5 \mathrm{mEq} / 1$. at this time would move $\mathrm{E}_{\mathrm{k}}$ even further away from $-90 \mathrm{mV}$. After still longer periods of ischaemia the situation reverts towards that seen before any occlusion occurred, despite the even more profound loss of intracellular potassium.

It is important to remember that the $E_{k}$ values referred to above relate to the muscle at the end of the ischaemic period and take no account of alterations occurring during subsequent reflow. There is evidence to suggest that the initial stages of reflow or recovery are accompanied by a further loss of tissue $\mathrm{K}$ (Jennings et al., 1964; Singh et al., 1969). We do not have sufficient data to indicate whether during the process of recovery the pattern seen in Fig. 3 retraces its steps or the rate and extent of the recovery process.

Nevertheless, if the interpretation of our data is correct it may explain the unpredictable incidence of dysrhythmic behaviour with respect to the serum $K$ and the response to intravenous potassium. Furthermore, if a specific pattern may be shown to occur during the recovery phase, and if it is reproducible, it may facilitate a less empirical approach to the management of arrhythmias. It would theoretically be possible to achieve this, not only by manipulating the serum $\mathrm{K}$ but also by selecting drugs according to the manner in which they affect the electric characteristics of the myocardial cell membrane.

We are grateful to Dr. Walter Somerville for his help, to the Clinical Research Committee of the Middlesex Hospital for facilities at the Institute of Clinical Research, and to the Institute of Nuclear Medicine for their collaboration. We are indebted to Mr. I. K. R. 
McMillan for his co-operation, and help in planning the study, and, together with Dr. Alan Johnson and Dr. Neville Conway, for permission to study patients under their care at the Southampton Chest Hospital Wessex Regional and Thoracic Centre; our thanks are also due to the staff of the theatre for their assistance and to Mr. Brian Augier for statistical advice.

This work was supported by a grant from the British Heart Foundation to one of us (P.T.)

\section{References}

Bettinger, J. C., Surawicz, B., Brylogle, S. W., Anderson, N., jun., and Bellet, S. (1956). American fournal of Medicine, 21, 521.

Ceremuzynski, L Staszewska-Barczac, J., and Herbaczynska-Cedro, $\mathrm{K}$ (1969). Cardiovacsular Research, 3, 190

Cotlove, E., Trantham, H. V., and Bowman, R. L. (1958). Fournal of Laboratory and Clinical Medicine, 51, 461.

Cox, W. V., and Robertson, H. F. (1936). American Heart fournal, 12, 285 Dennis, J., and Moore, R. M. (1938). American fournal of Physiology, $125,443$.

Ebert, P. A., Vanderbeek, R. B., Allgood, R. J., and Sabiston, D. C., jun (1970). Cardiovascular Research, 4, 141

Flear, C. T. G., and Florence, I. (1961). Clinica Chimica Acta, 6, 129.

Harris, A. S. (1966). American Heart fournal, 71, 797.

Harris, A. S., Bisteni, A., Russell, R. A., Brigham, J. C., and Firestone, J. E. (1954). Science, 119, 200.

Hoffman, B. F., and Cranefield, P. F. (1960). Electrophysiology of the Heart. New York, McGraw-Hill.
Iseri, L. T., Alexander, L. C., McCaughley, R. S., Boyle, A. J., and Myers, G. B. (1952). American Heart fournal, 43, 215.

Jennings, R. B., Sommers, H. M., Kaltenbach, J. P., and West, J. J. (1964). Circulation Research, 14, 260.

Klein, R., Haddown, J. E., Kind, C., and Cockburn, F. (1968). Metabolism, $17,1094$.

Langer, G. A. (1968). Physiology Review, 48, 708.

Levine, H. D., Merril, J. P., and Somerville, W. (1951). Circulation, 3, 889

McVie, J. G. (1970). fournal of Clinical Pathology, 23, 203.

Mandal, A. K., Callaghan, J. C., Dolan, A. M., and Sterns, L. P. (1969). Annals of Thoracic Surgery, 7, 428.

Paradise, R. R. (1963). Nature, 198, 112.

Prasad, K., and Callaghan, J. C. (1969). Annals of Thoracic Surgery, 7, 571. Raab, W. (1969). Annals of the New York Academy of Science, 147, 672.

Regan, T. J., Harman, M. A., Lehen, P. H., Burke, W. M., and Olderwortel, H. A. (1967). Fournal of Clinical Investigation, 46, 1957.

Schaal, S. F., Wallace, A. G., and Sealy, W. C. (1969). Cardiovascular Research, 3, 241

Shanks, R. G., and Dunlop, D. (1967). Cardiovascular Research, 1, 34.

Singh, C. M., Flear, C. T. G., and Ross, D. (1969). Second Annual Meeting of the International Study Group for Research in Cardiac Metabolism, p. 31. Pavia, Succ. Fusi.

Surawicz, B. (1966). Progress in Cardiovascular Diseases, 8, 364.

Taggart, P., and Slater, J. D. H. (1970). Clinical Science, 38, $26 \mathrm{P}$

Taggart, P., and Slater, J. D. H. (1971). In preparation.

Thomas, M., Shulman, G., and Opie, L. (1970). Cardiovascular Research, 4, 327 .

Vanderbeek, R. B., and Ebert, P. A. (1970). American fournal of Physiology,

Vick, R. L., Hazlewood, C. F., and Nichols, B. L. (1970). Circulation

Rugibe, F. T., Bell, P., jun., Conley, T., and Standish, M. L. (1966). Archives of Pathology, 81, 409.

\section{Smoking Risks of Different Tobaccos}

\section{R. D. PASSEY, MICHAEL BLACKMORE, DAVID WARBRICK-SMITH, RAYMOND JONES}

British Medical fournal, 1971, 4, 198-201

\section{Summary}

The smoke of English cigarettes (flue-cured tobacco) greatly shortens the life of rats and damages the respiratory system, whereas that of the cigar (air-cured tobacco) is relatively harmless. This bears out two of the principal features in the 1971 Report of the Royal College of Physicians, which draws attention to the large number of premature deaths in cigarette smokers and the comparative safety of smoking cigars.

\section{Introduction}

Before the present century lung cancer did not excite undue interest and presumably was reasonably constant in its incidence and mortality rate. This is no longer so. At the beginning of this century cancer of the lung was regarded as a rare disease. Now, in many countries, it is common, and in Britain it is the commonest recorded form of cancer in males. It is generally accepted that the increase is the result of the world-wide increase in the smoking of cigarettes. Yet cigarettes were being commonly smoked in the early years of the century.

Why is the ordinary cigarette itself so dangerous? In the Report of the Advisory Committee to the Surgeon-General on

Chester Beatty Research Institute, London S.W.3

R. D. PASSEY, M.D., D.P.H., Emeritus Professor of Experimental Pathology (Professor Passey died on 1 September 1971)

MICHAEL BLACKMORE, M.B., B.S., Research Assistant

DAVID WARBRICK-SMITH, Research Assistant

RAYMOND JONES, Research Assistant
Smoking and Health, 1964,* it was made clear (pages 108 and 112) that, while cigarettes shortened life and increased the lung cancer incidence, cigars in moderation-fewer than five a day-did not. This is surprising, since four American cigars are approximately the tobacco equivalent by weight of some 20 to 28 cigarettes. But if the smoker of 20 cigarettes per day has a $70 \%$ higher mortality rate, and a higher death rate from lung cancer than the non-smoker, why should the smoker of the same weight of tobacco in the form of cigars escape so easily?

\section{Present Investigation}

We set out to compare the effect on rats of the smoke of cigarette tobacco with the effect of the smoke of cigar tobacco under identical conditions. $\dagger$ To obtain identical conditions it was necessary to smoke the cigar tobacco in the same form as cigarette tobacco-namely, as cigarettes. So, at our request, and through the courtesy of the Tobacco Research Council, we obtained cigarettes made specially for us consisting entirely of cigar tobacco. The tobacco was cut in the same manner as cigarette tobacco and wrapped in cigarette paper, and in this manner the effects of paper and the different physical conditions of the tobacco were excluded from the experiment.

Groups of young rats were exposed to the smoke of these cigar cigarettes in a cabinet of a Martin Wright Smoking Machine and compared with groups exposed similarly to the smoke of a popular brand of English cigarettes. Control groups were maintained under the same conditions except that they were not exposed to tobacco smoke. All groups were fed Plowco 86 Laboratory Animals' Diet.

*U.S. Department of Health, Education, and Welfare, Public Health Service.

†As it is not possible to induce cancer of the lung in rats by exposure to cigarette smoke, that part of the human sequence of events is not reproducible. 